\title{
Genetic Variability and Divergence in Sorghum: Review
}

\author{
Werkissa Yali Kebbede* \\ Department of Horticulture and Plant Science, Ambo University, Ambo, P.O., Box 19, Ethiopia \\ *Corresponding Authors: Werkissa Yali Kebbede, Department of Horticulture and Plant Science, Ambo \\ University, Ambo, P.O., Box 19, Ethiopia
}

\begin{abstract}
Sorghum [Sorghum bicolor(L.) Moench], a cereal crop offamily Poaceae, is believed to be originated in Ethiopia and Sudan. It is an important food security crop mainly in semi-arid and tropical parts of the African countries. The crop is indigenous to Ethiopian as far as its domestication has long time and genetic diversity exhibited variation among cultivated and wild relatives of the crop concentrated in the country. The existence of tremendous amount sorghum variability exhibiting native genetic variation to drought, disease and insect resistance, having good grain quality and high lysine, made Ethiopia as genetic resource reservoir ranking first in contributing germplasm collection worldwide in today's sorghum breeding program. Ethiopian 'zera zera' sorghum landraces and line developed from them being involved in hybrid development at ICRISAT and other countries in modern sorghum breeding program. Currently, sorghum is the third important cereal crop in both area coverage and production becoming the second in 'injera' making after 'tef' in Ethiopia. Ethiopia has a diverse sorghum germplasm which adapted to a range of altitudes and rainfall conditions. Characterization and identification of sorghum germplasms which provide desirable traits for genetic improvement is a basis in plant breeding. DNA based molecular marker and PCR based are the best to characterize and identify sorghum genotypes which provide desirable traits as compared to field experimental evaluation due to time and environmental effect. Genetic improvement is the cost-effective means of enhancing sorghum productivity for different end-uses. A better understanding of the genetic diversity in sorghum would greatly contribute to crop improvement with a view to food quality and other important agronomic traits. The Ethiopian Center of Crop Diversity contains enormous wealth of genetic variability in the sorghums. It needs some concerted effort to adequately collect and preserve this genetic variability before it is invaded and destroyed.
\end{abstract}

Keywords: sorghum, genetic variability, germplasm, genotype, diversity

\section{INTRODUCTION}

Sorghum [Sorghum bicolor (L.) Moench], a cultivated diploid $(2 \mathrm{n}=20)$ tropical cereal C4 grass plant, is the fifth most important cereal crop grown in the world. It is a monocotyledon plant of tropical origin, belonging to Poaceae family(Nagara, 2017). Sorghum is called as camel of crops due to the high tolerance of water and temperature stress and also high photosynthesis efficiency; it is considered as an important plant in arid and semi-arid regions (Anagholi et al., 2000).

Ethiopia is known to be one of the Vavilovian centres of origin, or diversity for many cultivated and wild species of crops, including sorghum. Sorghum is one of the cereal crops for which Ethiopia has been credited as being a center of origin and/or diversity. In the high altitude areas, the landrace sorghum germplasm has often been the only well-adapted material that is easily accessible for use(Tesfaye, 2017). There is a higher probability of genetic material exchange to occur between the wild (Sorghum bicolor sub sp. arundinaceum) and the cultivated sorghum since both types mostly grow in sympathy with the wild and weedy relatives in most sorghum-growing parts of Ethiopia, mainly in the southeastern and south-western part of the country Doggett, H. (1988). A greater extent of genetic diversity existed within a species, often used as a measure of its ability to adapt to its new environment. Ethiopia is the sixth largest sorghum producing country in the world with sorghum contributing $16.4 \%$ of the total annual cereal grain production and is ranked third in both total area coverage and productivity. Currently, the national average productivity of sorghum in Ethiopia is 2.5 tons/ha (CSA, 2017).

Admas and Tesfaye, 2018 described as sorghum is native to Ethiopia and it has remarkable genetic diversity as evidenced by many landrace collections made in the country. It is well adapted to a wide range of environmental conditions in semi-arid Africa. It is mainly produced in medium and lowlands of Ethiopia. It with stands hot and dry condition better than most cultivated crops in Ethiopia. Sorghum 
is grown for its grain used as food and local beverages; nowadays, its stalk has also become an alternate source of animal feed as well as fuel. However, the average yield trends are downwards.

The largest diversity of the crop germplasm provides greater opportunities for improvement regarding its environmental adaptability and acquiring better agronomic traits from the crop species. Identifying and selecting the best varieties meeting specific local food and industrial requirements from this great biodiversity is of high importance for the food security assurance of any given country (Dahlberg et al., 2002).

Genetic variability is prerequisite in the existing population for varietal improvement. Loss of genetic variability leading to genetic erosion has led to greater emphasis on germplasm collection and characterization for present and future plant breeding programmes (Prasanna, 2010). Knowledge of genetic diversity of a crop usually helps the breeder in choosing desirable parents for the breeding program and gene introgression from distantly related germplasm. The more diverse genotypes or accessions can be crossed to produce superior hybrids with resistance to abiotic and biotic stresses (Elangovan and Babu, 2015). Understanding the wealth of genetic diversity in sorghum will facilitate the further improvement of this crop for its genetic architecture.

Genetic diversity in the crop species is the gift of nature and arises due to geographical separation or due to genetic barriers to cross ability. Morphological traits are conventional tools to analyze the genetic diversity (Prasanna, 2010). Morphological assays generally require neither sophisticated equipment nor preparatory procedures. They are generally simple and inexpensive to score. These easily observable quantitative morphological traits are a useful tool for preliminary evaluation because they offer a fast and useful approach for assessing the extent of diversity. Over the years, a number of studies have dealt with estimating genetic diversity in cultivated sorghum using morphological traits. The use of morphological traits is the most common approach utilized to estimate relation- ships between genotypes. The genetic variability of cultivated species/varieties and their wild relatives together form a potential and continued source for the development of improved crop varieties(Ahalawat et al., 2018).

A better understanding of the genetic diversity in sorghum would greatly contribute to crop improvement with a view to food quality and other important agronomic traits. Therefore, there is a need to evaluate the available accessions for genetic diversity and identify the best accessions according to their performance. There are around 11,353 sorghum accessions collected and conserved in Ethiopian Biodiversity Institute gene bank, of which 8,913 accessions were characterized by plant breeders and other researchers, and further 2,440 sorghum accessions are yet to be screened for their potentially useful characters(Tesfaye, 2017). Therefore, this paper was prepared with the objectives of reviewing the genetic variability and divergence of sorghum in Ethiopia

\section{LITERATURE REVIEW}

\subsection{Origin, Distribution and Adaptability of Sorghum}

Ethiopia is the Vavilovian centers origin/diversity for sorghum (Vavilov, 1951). Sorghum originated in Africa, more known in Ethiopia, between 5000 and 7000 years ago (ICRISAT, 2005). Then, it was distributed along the trade and shipping routes around the African continent, and through the Middle East to India at least 3000 years ago. It then journeyed along the Silk Route into China (Dicko et al., 2006). It was first taken to North America in the 1700-1800's through the slave trade from West Africa and was re-introduced in Africa in the late 19th century for commercial cultivation and spread to South America and Australia(Yitayeh, 2019).

Currently sorghum is widely found in the dry lowland areas of Africa, Asia (India and China), the Americas and Australia (Dicko et al., 2006). It is an economically, socially and culturally important crop grown over a wide range of ecological habitats in Ethiopia, in the range of 400-3000 m.a.s.1 (Teshome et al., 2007). Sorghum is a unique cereal crop in the lowland areas due to its drought tolerance (Kebede, 1991).

\subsection{Importance of Sorghum}

\subsubsection{Global Context}

Sorghum [Sorghum bicolor (L.) Moench] is a C4 tropical crop which originated and was domesticated in Ethiopia and the surrounding Eastern quadrants of Africa where both the cultivated and wild relatives 
co-exist (Dillon et al., 2007).As compared to other cereals, sorghum is a drought tolerant crop and able to withstand low soil fertility (Tolk et al., 2013). It is a main crop for more than 500 million people in the developing world mainly in the 30 sub Saharan Africa and Asian countries (Kumar et al., 2011), but it is also grown as a feed crop in the developed world. In addition, sorghum is a preferred feedstock for biofuel production due to its high biomass production and high water use efficiency (Packer and Rooney, 2014).

The sorghum production area globally has shown a mixed trend, and while the overall sorghum production area has declined from year to year mainly in USA, China and India, there is a steady increase in production area in most African countries (especially Sub Saharan Africa) and Australia (Rakshit et al., 2014). Sorghum productivity over the past four decades has shown a yield improvement of 1 to $4 \%$ per year in many countries including USA, Australia, and China (Rakshit et al., 2014). The increased productivity of sorghum has maintained the total production and it has remained the fifth most important cereal crop in total grain production in the world (Kumar et al., 2011). The sorghum grain produced has contributed $2.7 \%$ of the top five major cereal grain produced globally over the past decade (FAOSTAT, 2015).

The increase in sorghum productivity is the outcome of both improved varieties and improved management practices. The use of hybrid varieties with improved management have been provided in yield increases that have been achieved in many developed and a few developing countries (Kumar et al., 2011). To-date the total sorghum production area in USA and Australia is planted to hybrids and in China and India more than eighty five \% of sorghum growing areas is planted with improved varieties including hybrids ( Rakshit et al., 2014). The adoption of hybrids has contributed to increased sorghum productivity in many countries, for instance in China productivity has increased by $3.9 \%$ and in India by $2 \%$ per annum (Rakshit et al., 2014).

\subsubsection{Importance of Sorghum in Ethiopia}

According to the CSA, 2014 Ethiopia is the sixth largest sorghum producing country in the world with sorghum contributing $17 \%$ of the total annual cereal grain production. Sorghum has a wider agroecological adaptation in Ethiopia and is cultivated in the three major agro-ecological zones in the country, which can be broadly classified into highlands $>1900$ meter above sea level (masl), intermediate between 1600-1900masl and lowland agro-ecologies <1600masl (Tesso et al., 2011). Gebeyehu et al., 2004 also states as it is the dominant crop in the dry lowlands which accounts for 66\%, on average, of the total cultivated areas of the country. There are a wider ranges of sorghum production systems that can be differentiated in relation to the amount of rainfall received and targeted uses (Gerorgis, 1990; Wortmann CS, 2009). Multiple cropping systems has been practiced in low moisture areas to overcome the effect of drought (Gerorgis, 1990) and sole cropping has been reported as the dominant cropping system in the major sorghum growing area of Ethiopia (Wortmann CS, 2009). The very complex production systems and the very diverse growing environments have been the challenge for the development and dissemination of improved technology.

Since 2008 the total area covered with sorghum annually has increased by $0.78 \%$ and productivity has increased by $6.2 \%$ (CSA, 2014). The increase in productivity has come despite the fact that more than $90 \%$ of the total sorghum area is cultivated by small holder farmers who mainly use traditional methods of cultivation which is characterized by low utilization of improved varieties and fertilizers. Fertilizer (both natural and commercial) has only applied to $2.4 \%$ of the total area cultivated with sorghum (CSA, 2014). The overall increase in productivity could therefore be related to the genetic potential of farmers selected varieties (Mekbib, 2006) and use of improved management practices including row spacing and tied ridge to conserve moisture.

The majority of the grain produced (74\%) is used for household consumption with the remaining proportion being used for sale and seed purpose (CSA, 2014). Sorghum grain is preferred next to tef, a small cereal grain crop, for the preparation of the staple leavened bread (injera). Although there is variability in the grain quality depending on the end use product, larger seed size, while and light red types of sorghum grains are predominantly preferred for the preparation of injera. The grain has also use for the preparation of locally prepared beverages and the stover used as animal feed, fuel wood and construction purposes(Yitayeh, 2019). 


\subsection{Genetic variability in sorghum}

\subsubsection{Taxonomic Classifications and Races}

It was believed that there were 20 to 30 species of genus Sorghum that are recognized until now, and these are classified into five sections: Stiposorghum, Parasorghum, Eu- sorghum, Heterosorghum and Chaetosorghum. Under the section Eu-sorghum, three species are recognized: S. halepense (L.) Pers. occurring in India, S. propinquum (Kunth) Hitchc found in Southeast Asia and S. bicolor (L.) Moench, which originated in Africa (De Wet, 1978). All classified under genus Sorghum. De Wet's recognized S. bicolor (L.) Moench representing all annual cultivated, wild and weedy sorghums along with two rhizomatous taxa, S. halepense and S. propinquum. All types of the S. bicolor (the primitives) propagated with seeds except the rhizomatous taxa's which reproduces through both seed and rhizome production. Sorghum bicolor was further broken down into three subspecies: S. bicolor sub sp bicolor, S. bicolor sub sp drummondii and S. bicolor sub sp verticilliflorum. The cultivated sorghums are classified as S. bicolor sub sp bicolor and represented by agronomic types such as grain sorghum, sweet sorghum, Sudan grass and broom corn.

All the cultivated sorghum taxa of the world have been classified by inflorescence type, grain and glumes into five races (Durra, Bicolor, Caudatum, Kaffir and Guinea) and intermediates involving all of the pair-wise combinations of the basic races (de Wet, 1978; Harlan and de Wet, 1972). The entire races were differentiated morphologically based on their inflorescence, grain and glumes. The race bicolor has its grain elongated, with glumes clasping the grain, which may be completely covered or exposed. This race is mostly grown west of the Rift valley and also on a minor scale almost everywhere in Africa. Guinea is primarily West African with a secondary centre in Malawi and Tanzania. The grain is flattened dorso-ventrally, twisting at maturity 90 degrees between glumes that are nearly as long as or longer than the grain. The caudatum grain is asymmetrical, with glumes half the length of the grain or less. This race is most abundant in east Nigeria, Sudan and Uganda. Kafir is mostly a race of east and Southern Africa. It has symmetrical grain, with glumes of variable length clasping the grain. Durra is dominant in Ethiopia and westward across the continent, covering the driest parts near the Sahara. Its grain is rounded and the glumes are very wide (House, 1985).

Four of the five sorghum races and wild forms are present in Ethiopia except Kaffir (Awegechew Teshome et al., 1997). Stemler et al., (1977) described and discussed the diversity of sorghum grown in Ethiopia for the races Bicolor, Durra, Durra-Bicolor, Caudatum and Guinea based on Ethiopian sorghum collections and field observations. The geographic pattern of distribution of each race appears to be determined by the topography and climate variation present in Ethiopia. Accordingly, sorghum race Durra is the main crop of the eastern highland region and mid elevation terrace of the north, while Caudatum race is grown primarily in hot, dry valleys and lowland savannas in the south and west of Ethiopia. The intermediate race Durra-Bicolor predominates in the southwestern highland region, where cooler temperature and rain are higher than eastern and northern region. In contrast, Bicolor and Guinea races represent a very small part of Ethiopian sorghum diversity and both are mostly found in the Rift Valley region.

Qualitative morphology characterization work on Ethiopian landraces along with introduced lines of sorghum from abroad and neighboring Eritrean accessions also shows the differential distribution of these different panicle types. This indicated the adaptive significance of panicle compactness and shape reflected the distribution patterns of different races of sorghum in Ethiopia. In their studies, the patterns of distribution of the different panicle types appeared to follow the temperature, humidity and rainfall patterns of Ethiopia and Eritrea. The compact and semi-compact panicle types were more frequent in Eritrea and in relatively hot and dry regions of Ethiopia such as Hararge, Tigray and Wello. The loose panicle types with dropping branches occurred abundantly in relatively cool and wet regions of Ethiopia such as Wollega, Illubabor, Shewa and Sidamo (Amsalu Ayana and Endashaw Bekele, 1998).

\subsubsection{Sorghum Genetic Variability in a Globally}

Characterization and identification of sorghum genotypes conferring important traits for genetic improvement is a prerequisite in plant breeding activities. Kimber et al (2013) presented details of the major world sorghum collections and breeding lines that total over 150,000 accessions. Morphological variability of sorghum has been used for the development of global core collections which represent the world collections for effective utilization in plant breeding (Dahlberg et al., 2004). However, the time required for phenotyping and the impact of environmental effects on trait expression limits the utility 
of morphological traits for characterization and diversity analysis of germplasm collections. The discovery of different types of DNA based molecular marker systems provided opportunities to effectively characterize and structure large number of genotypes without any effect of seasonality. Hybridization based RFLPs (Restricted Fragment Length Polymorphism) markers were the first DNA marker system identified that could differentiate homozygote and heterozygote loci (Botstein et al., 1980). RFLP markers have been used for genetic variability studies in many different crops including in sorghum. The RFLP marker system is technically demanding, however, and found not to be suitable for high throughput and low cost screening. The polymerase chain reaction (PCR) technique was invented in 1983 (Bartlett and Stirling, 2003) and provide a revolutionary approach to increase both sample throughput and sample cost for marker screening.

PCR based marker systems include RAPDs (Random Amplified Polymorphism) (Williams et al., 1990), ISSRs (Inter Simple Sequence Repeats (Zietkiewcz et al., 1994); AFLPs (Amplified Fragmented Length Polymorphism) and SSRs (Simple Sequence Repeat) all of which have been widely used in various studies in many crops including in sorghum (Agrama and Tuinstra, 2003).Both RAPD and AFLP markers are dominant markers which are not able to differentiate homozygous from heterozygous loci. Additionally these marker types have been shown to have limited repeatability across laboratories (Collard et al., 2005) as well as being very time consuming, both of which has limited the utility of these markers.

However, SSR markers require sequence information and generation of polymorphic markers can be time consuming and expensive, and hence their applications are restricted to specific crops (Semagn et al., 2006).Both the hybridized and PCR based markers have had a wide range of applications to sorghum. A recent genetic variability study of global reference set of sorghum genotypes using SSR markers revealed that landraces originating from Africa had the largest number of polymorphic alleles and the Eastern African genotypes had the highest variability followed by western African genotypes (Billot et al., 2013). Genetic variability and the genetic basis of racial classifications in sorghum have also been studied using different types of DNA based markers (Brown et al., 2011). Previous studies have been reflected the correspondence between the racial classifications based on morphological traits and the grouping of sorghum genotypes based molecular marker based genetic distance which also reflected the geographical distribution of sorghum, with the exception of the bicolor race (Brown et al., 2011). The bicolor racial types have been found to be the most primitive and diverse in comparison to the other four races, while the least genetic variability was observed in the kafir race (Billot et al., 2013). Distinct groupings of sorghum accession and inbred lines have also been reported to be used as a source of breeding lines using SSR markers (Agrama and Tuinstra, 2003).

The recent advent of next generation sequencing techniques (NGS) has offered new opportunities for sequencing and resequencing whole-genomes or targeted regions of genome. Genotyping by sequencing (GBS) has been introduced as a tool to discover polymorphic markers while genotyping with high-throughput sequencing approaches with a low cost per data point (Poland and Rife, 2012). The recent resequencing of multiple sorghum genotypes revealed the structuring of genotypes based on racial grouping and also identified novel genetic variability which could be useful for genetic improvements activities. In addition, genome-wide markers generated by GBS have also been used for diversity analysis and understanding the genetic basis of complex traits and adaptation in sorghum (Wang et al., 2013).

\subsubsection{Genetic Variability of Ethiopian Sorghum Genotypes}

All five major races of sorghum have been identified in the Ethiopian sorghum collections, with the durra and bicolor racial types and their derived sub-races predominating (Doggett, 1988). The zerazera type of sorghum, which originated on the border between Ethiopia and Sudan which is the sub-type of the race caudatum, is known for its grain appearance or grain type and disease resistance and has been used widely in many plant breeding programs (Prasada Rao and Mengesha, 1981). In addition, the Ethiopian sorghum collections have been used as a source of genes for important agronomic traits globally, including stay green genes for post flowering drought tolerance (Kebede et al., 2001), better grain quality and increased yield potential (Prasada Rao and Mengesha, 1981) and high lysine and enhanced protein digestibility and starch digestibility.

A number of genetic variability studies of Ethiopian sorghum genotypes adapted to the different agroecologies have been conducted using qualitative and quantitative traits. Significant variation for 
qualitative traits has been reported using 34 sorghum landraces obtained from five of the main sorghum growing areas of the country (Abdie et al., 2002). Genetic variability studies for both qualitative and quantitative traits using genotypes representing specific and across the different sorghum growing regions have also been conducted (Ayana and Bekele 1998; Desmae, 2007) and have shown the extent of genetic variation in addition to differentiation of panicle compactness and shape according to geographic regions (Abdie et al., 2002; Ayana and Bekele, 1998). In contrast, a study by (Ayana et al., 2000) has reported a weak genetic differentiation based on agro-ecological adaptations and regions using 80 sorghum landraces genotyped based on the genetic distance computed using 20 RAPD markers. A large set of accessions from the Northern part of the country, genotyped using SSR and ISSR markers, also showed the high variability among accessions with limited variability among geographic origins (Desmae, 2007). Such low differentiation among the regions could be due to gene flow due to exchange of seed between regions; however, the limited number of markers used for both studies may have also impacted on the result. A high level of marker polymorphism has been reported between 45 Ethiopian sorghum landraces from the Eastern highland agro-ecology using SSR and AFLP markers (Geleta et al., 2006).

A recent study using SSR markers also identified the enormous genetic variability present within the Ethiopian sorghum collections maintained in USA, National Plant Germplasm System, in comparison to accessions obtained from different countries of origin. Such a high level of diversity within Ethiopian genotypes was also found in the recent whole genome resequencing study in sorghum which highlighted the potential for using previously untapped diversity for genetic gain through breeding (Mace et al., 2013).

\subsubsection{Germplasm Resources and Collections}

Ethiopia is the center of origin and diversity for many crops including sorghum (Vavilov, 1951). There is huge source high lysine (Singh and axtell, 1973), good grain quality and resistance to disease and insect (Yilma, 1991) and post flowering drought tolerance (stay-green trait) (Borrel et al., 2000). Primarily, considering genetic variability and diversity of sorghum in Ethiopia, collection started in between 1958 and 1960 by Jimma Agricultural Technical School(Chala, 2018). Later this activity was taken over by ESIP and continued collections since the 1970s (IBC, 2012). After ESIP started in fullscale in 1973, it served as home for the popular zera zeras (caudatum race) type sorghums, which were extensively used as parents in ICRISAT sorghum improvement programs until the 1990s and being extremely provided germplasm for the improvement of food type sorghums (Reddy et al., 2004). Through the early 1980s only, ESIP had amassed a collection of approximately 5500 accessions (Doggett, 1988). Nationally, the ESIP made good progress with release of the varieties, Awash 1050, the popular ETS series, and Gambella 1107 (E 35-1) that has been widely used in ICRISAT breeding programs (Reddy et al., 2004).

In general, about 9, 824 sorghum germplasm accessions were collected and maintained by ESIP and the Institute of Biodiversity Conservation (IBC). Recently, diverse source of more than 10,000 sorghum accession were collected and conserved in Ethiopian Institute of Biodiversity and Conservation (EIBC); consisting diversity form cultivated and its wild relatives represent possible of germplasma for crop improvement and providing source of noble traits (EIAR, 2014).

\subsubsection{Importance of Genetic Diversity}

Genetic diversity is the base for survival of plants in nature and for crop improvement. Diversity in plant genetic resources provides opportunity for plant breeders to develop new and improved cultivars with desirable characteristics, which include both farmer-preferred traits (high yield potential, large seed, etc.) and breeder-preferred traits (pest and disease resistance and photosensitivity, etc.). From the very beginning of agriculture, natural genetic variability has been exploited within crop species to meet subsistence food requirement. Later the focus shifted to grow surplus food for growing populations. Presently the focus is on both yield and quality aspects of major food crops to provide balanced diet to human beings(Bhandari et al., 2017).

With changing climatic scenario, breeding of climate resilient varieties is becoming more important. The existence of genetic diversity represented in the form of wild species, related species, breeding stocks, mutant lines etc. may serve as the source of desirable alleles and may assist plant breeders in breeding climate resilient varieties. The breeding of climate resilient varieties requires novel traits like 
tolerance towards potential new insect-pests and diseases, extreme heat, extreme cold, and towards various air- and soil- pollutants. For ever-changing breeding goals, different genes need to be reserved in cultivated and cultivable crops species in the form of germplasm resources. Presence of genetic diversity within and between crop plant species permits the breeders to select superior genotypes either to be directly used as new variety or to be used as parent in hybridization programme. Genetic diversity between two parents is essential to realize heterosis and to obtain transgressive segregants.

Genetic diversity facilitates breeders to develop varieties for specific traits like quality improvement and tolerance to biotic and abiotic stresses. It also facilitates development of new lines for nonconventional uses like varieties for biofuel in sorghum, maize etc. Diversity is also important with respect to adaptability of crop plants to varied environments with special reference to changing climatic conditions(Bhandari et al., 2017).Sorghum is believed to have a wide range of diverse germplasm. Plant genetic resources play an important role in generating new high yielding crop varieties with desired traits. Various research methodologies are employed in in situ and ex situ conservation of genetic diversity in plants. The amount of genetic diversity and rate of genetic erosion is quantified in various crops using different methods and models (Shehzad and Okuno, 2014)

\section{CONCLUSION AND RECOMMENDATION}

The challenge for young plant breeders is to create enough genetic variability to keep improving genetic yield potential. Plant breeders might utilize exotic non adapted material, exotic adapted material or existing elite material as a source of new alleles that will protect and improve genetic gain through selection.

Plant breeding is facing challenge to feed the ever increasing population with diminishing cultivable land. Modern plant breeding has achieved some success in this regard. However, it has resulted in the genetic vulnerability because of narrow genetic base of cultivated varieties in many crops. Hence, there is a need of paradigm shift in plant breeding focussing on diverse genetic resources. Genetic diversity has now been acknowledged as a specific area that can contribute in food and nutritional security. Better understanding of genetic diversity will help in determining what to conserve as well as where to conserve. Genetic diversity of crop plants is the foundation for the sustainable development of new varieties. So there is a need to characterize the diverse genetic resources using different statistical tools and utilize them in the breeding programme. Morphological data in conjunction with molecular data are used for precise characterisation of germplasm resources. With the advent of high throughput molecular marker technologies it is possible to characterize larger number of germplasm with limited time and resources.

In summarizing, the Ethiopian Center of Crop Diversity contains enormous wealth of genetic variability in the sorghums. It needs some concerted effort to adequately collect and preserve this genetic variability before it is invaded and destroyed by improved uniform varieties and modern technology.

\section{ACKNOWLEDGEMENT}

The reviewer acknowledged the Researchers who had studied improvement of sorghum genetic variability and divergence.

\section{REFERENCES}

[1] Abdie A, Bekele E, Asfaw Z, Teshome A ( 2002) Pattern of morphological variation of sorghum (Sorghum bicolor (L) Moench) landraces in qualitative characters in North Showa and south Wello. Hereditas 137: $161-172$.

[2] Admas, S. and Tesfaye, K. (2018) 'Genotype-by-environment interaction and yield stability analysis in sorghum (Sorghum bicolor (L.) Moench) genotypes in North Shewa, Ethiopia', Acta Universitatis Sapientiae, Agriculture and Environment, 9(1), pp. 82-94. doi: 10.1515/ausae-2017-0008.

[3] Agrama HA, Tunistra MR (2003) Phylogenetic diversity and relationships among sorghum accessions using SSRs and RAPDs. Afr J Biotec 2:334 - 340.

[4] Ahalawat, N. K. et al. (2018) 'Genetic divergence in forage sorghum ( Sorghum bicolor L . Moench )', 10(1), pp. 439-444.

[5] Amsalu Ayana and Endashaw Bekele (1998). Geographical patterns of morphological variation in sorghum ( Sorghum bicolor ( L .) Moench ) germplasm from Ethiopia and Eritrea : qualitative characters. Hereditas 129: 195-205. 
[6] Anagholi A, Kashiri A, Mokhtarpoor H (2000). The study of comparison between inside forage sorghum cultivars and speed feed hybrids. Agricultural Science and Natural Resources Journal 7(4):73-83.

[7] Awegechew Teshome, Baum, B.R., Fahrig, L., Torrance, J.K., Arnason, T.J. and Lambert, J.D. (1997). Sorghum (Sorghum bicolor (L.) Moench) landraces variation and classification in north Shewa and south Welo, Ethiopia. Euphytica 97:255-263.

[8] Ayana A, Bryngelsson T, Bekele E (2000) Genetic variation of Ethiopian and Eritrean sorghum (Sorghum bicolor (L.) Moench) germplasm assessed by random amplified polymorphic DNA (RAPD). Genet Resour Crop Ev 47:471-482.

[9] Ayana, A., \& Bekele, E. 1998. Geographical patterns of morphological variation in sorghum (Sorghum bicolor (L.) Moench) germplasm from Ethiopia and Eritrea: Qualitative characters. Hereditas 129:195- 205

[10] Bartlett JMs, Stirling D (2003) A short history of the polymerase chain reaction. In: Bartlett JMS, Stirling D (eds) PCR protocols. Humana Press pp. 3-6.

[11] Bhandari, H. R. et al. (2017) 'Assessment of genetic diversity in crop plants - an overview', 7(3), pp. 279286. doi: 10.15406/apar.2017.07.00255.

[12] Borell, A.K., Hammer, G.L., and Douglas, A. C.I. 2000. Does maintaining green leaf area in sorghum improve yield under drought. Leaf growth and senescence. Crop Science 40:11026-103

[13] Botstein D, White RL, Skolnick MH, Davies RW (1980) Construction of a genetic map in man using restriction fragment length polymorphism. Am J Hum Genet 32: 314-331

[14] Bowers J, Abbey C, Anderson S, Chang C, Draye X, et al (2003) A high-density genetic recombination map of sequence-tagged sites for sorghum, as a framework for comparative structural and evolutionary genomics of tropical grains and grasses. Genetics 165:367-386.

[15] Brown PJ, Myles S, Kresovich S (2011) Genetic Support for Phenotype-based Racial Classification in Sorghum. Crop Sci 51:224-230.

[16] Central Statistical Agency of Ethiopia (CSA) (2014) Agricultural Sample Survey 2013/2014. Stat Bull 532.

[17] Central Statistical Agency of Ethiopia (CSA) (2017). Agricultural Sample Survey 2016/2017. Stat Bull, 584.

[18] Chala, C. B. (2018) 'Sorghum [ Sorghum bicolor ( L .)] Breeding in Ethiopia : Review', 8(21), pp. 81-94.

[19] Collard BCY, Jahufer MZZ, Brouwer JB, Pang ECK (2005) an introduction to markers, quantitative trait loci (QTL) mapping and marker-assisted selection for crop improvement: The basic concepts. Euphytica 142:169-196

[20] Dahlberg JA, Burke JJ, Rosenow DT (2004) Development of a sorghum core collection: refinement and evaluation of a subset from Sudan. Econ Bot 58:556-567.

[21] Dahlberg, J. A., Zhag, X., Hart, G. E., Mullet, J. E. (2002), Comparative assessment of variation among sorghum germplasm accessions using seed morphology and RAPD measurements. Crop Science Journal 42(1), 291-296.

[22] De Wet, J. M. J. (1978). Systematics and evolution of Sorghum Sect. sorghum (Graminae). American Journal of Botany 65:477.

[23] Dicko, M.H., Gruppen, H., Traore, A.S., Alphons, G.J., Voragen, A.G.J. and Berkel, W.J.H.van. (2006). Sorghum grain as human food in Africa: Relevance of content of starch and amylase activities. African Journal of Biotechnology, 5: 384-395.

[24] Dillon SL, Shapter FM, Henry RJ, Cordeiro G, Izquierdo L, Lee LS (2007). Domestication to Crop Improvement: Genetic Resources for Sorghum and Saccharum (Andropogoneae). Ann Bot 100:975-989.

[25] Doggett H 1988. Sorghum. 2nd ed. Longman Group UK Limited.

[26] EIAR (Ethiopian Agricultural Research Institute) [2014]. Ethiopian Strategy for Sorghum. EIAR, Addis Ababa, Ethiopia Pp28.

[27] Elangovan M. and Babu P. K. (2015). Genetic variability and diversity of sorghum land race collected from Uttar Pradesh India. Indian Journal of plant genetic re- sources, 28(2):213 22

[28] Food and Agriculture organization of the United Nation statistical division (FAOSTAT), 2015. http://faostat3.fao.org/home/E

[29] Frew Mekbib (2008). Genetic erosion of sorghum (Sorghum bicolor (L.) Moench) in the centre of diversity, Ethiopia. Genetic Resources and Crop Evolution 55: 351-364.

[30] Gebeyehu G, Asfaw A, Taye T, Tesefaye T, Ketema B, Hailemichael H. (2004). Development of sorghum varieties and hybrids for dry land areas of Ethiopia. Uga J Agri Sci 9:594-605

[31] Geleta N, Labuschagne MT, Viljoen C (2006) Genetic diversity analysis in sorghum germplasm as estimated by AFLP, SSR and Morpho agronomical markers. Biodivers Conserv 15:3251- 3265 
[32] Georgis K, Abebe A, Negasi A et al. (1990). Cereal-legume intercropping research in Ethiopia. In: Waddington SR, Palmer AFE, Edje OT (eds) Research methods for cereal legume intercropping. Proc. Workshop on Research Methods for Cereal/Legume Intercropping in Eastern and Southern Africa. CIMMYT. P167-175.

[33] Harlan, J.R. and de Wet, J.M.J. (1972). Simplified classification of cultivated sorghum. Crop Science. 12: $172-176$

[34] House, L. R. (1985). A Guide to Sorghum Breeding, Second Edition. International Crops Research Institute for the Semi-Arid Tropics, Andhra Pradesh 502, India.

[35] IBC (Institute of Biodiversity Conservation). 2012. Third Country Report on the State of Plant Genetic Resources for Food and Agriculture, Adis Abeba, Ethiopia pp.10-15

[36] ICRISAT (International Crop Research Institute for Semi-Arid Tropics) [2005]. Sorghum report. http://www.icrisat.org/text/research/grep/homepage/sorghum/sorghumhomepage.htm Online. Patancheru, India.

[37] Kebede H, Subudhi PK, Rosenow DT, et al. (2001) Quantitative trait loci infl uencing drought tolerance in grain sorghum ( Sorghum bicolor L. Moench). Theor Appl Genet 103:266-276.

[38] Kebede, Y. (1991). The role of Ethiopian sorghum germplasm resources in the national breeding program. In: J.M., Engels, J. G. Hawke and M. Worede, (Eds.), Plant Genetic Resources of Ethiopia. Cambridge University Press, Cambridge, 315-322 pp.

[39] Kimber CT, Dahlberg JA, Kresovich S (2013) The Gene Pool of Sorghum bicolor and Its Improvement. In: Paterson A.H. (ed.) Genomics of the Saccharinae, Plant Genetics and Genomics: Crops and Model. 23-41, Springer Science, Media New York.

[40] Kumar AA, Reddy BVS, Sharma HC, Hash CT, Rao PS, Ramaiah B, Reddy PS., 2011. Recent advances in sorghum genetic enhancement research at ICRISAT. Am J Plant Sci 2:589 600.

[41] Mace ES, Tai S, Gilding EK, Li Y, Prentis P, Bian L, Campbell B, Hu W, Innes DJ, Han X. et al (2013) Whole-genome sequencing reveals untapped genetic potential in African's indigenous cereal crop sorghum. Nat Commun 4:2320.

[42] Mekbib F (2006) Farmer and formal breeding of sorghum (Sorghum bicolor (L.) Moench) and the implications for integrated plant breeding. Euphytica 152:163-176.

[43] Nagara, G. O. (2017) 'Genetic Diversity Analysis of Sorghum [ Sorghum bicolor ( L .) Moench ] Races in Ethiopia Using SSR Markers'.

[44] Packer D J, Rooney WL. (2014). High-parent heterosis for biomass yield in photoperiod-sensitive sorghum hybrids. Field Crop Res 167:153-158.

[45] Paterson AH, Bowers JE, Chapman BA (2004) Ancient polyploidization predating divergence of the cereals, and its consequences for comparative genomics. Proc Natl Acad Sci USA 101:9903- 9908.

[46] Paterson AH, Bowers JE, Feltus FA (2008) Genomics of Sorghum, a Semi-Arid Cereal and Emerging Model for Tropical Grass Genomics. In: Moore P.H., Ming R (eds). Genomics of Tropical Crop Plants. Springer 469:482

[47] Paterson et al., 2009. The sorghum bicolor genome and the diversification of grasses. Nature 457: 551-556.

[48] Prasada Rao KE, Mengesha MH (1981) A pointed collection of zera-zera sorghum in the Gambella area of Ethiopia. Genetic Resources Units Progress Rep. No. 33. ICRISAT, Patancheru, India.

[49] Prasanna, B.M. (2010). Phenotypic and molecular diversity of maize landraces: characterization and utilization. The Indian Journal of Genetics and Plant Breeding, 70:315- 327

[50] Rakshit S, Hariprasanna K, Gomashe S, Ganapathy KN, Das IK, Ramana OV, Dhandapani A, Patil JV. (2014). Changes in Area, Yield Gains, and Yield Stability of Sorghum in Major Sorghum Producing Countries, 1970 to 2009. Crop Sci 54:1571-1584.

[51] Reddy, B.V.S, Rao P., Deb, U.K, Stenhouse, J.W., Ramaiah, B. and Ortiz, R. 2004. Global sorghum genetic enhancement processes at ICRISAT. Pp.65-102 in Sorghum genetic enhancement: research process, dissemination and impacts (Bantilan MCS, Deb UK, Gowda CLL, Reddy BVS, Obilana AB and Evenson RE, eds.). Patancheru 502 324, Andhra Pradesh, India: International Crops Research Institute for the SemiArid Tropic

[52] Rooney WL (2004) Sorghum Improvement-Integrating Traditional and New Technology to Produce Improved Genotypes. In: Advance in agronomy. 83: 37-109

[53] Rosenow, D.T., Dahlberg, J.A., Paterson, G.C., Clark, L.E., Sotomayor, R.A., Miller, F.R., Hamburger, A.J., Madera-Torres, P., Quiles-Belen, A., and Woodfin, C.A. 1995. Release of 50 converted sorghum lines and 253 partially converted sorghum bulks. International Sorghum and Millets Newsletter 36:19-31. 
[54] Rosenow, D.T., Ejeta, G., Clark, L.E., Gilbbert, M.L., Henzell, R.G., Borrell, A.K., Muchow, R.C. 1996. Breeding for pre-flowering and post-flowering drought stress in sorghum.In: proceedings of the international conference on genetic improvement of sorghum and pearl millet.Lubbock, Texas. INTSORMIL and ICRISAT publication No. 97-5. pp. 400-411

[55] Shehzad, T. and Okuno, K. (2014) 'Review article Diversity assessment of sorghum germplasm and its utilization in genetic analysis of quantitative traits-A review', 8(6), pp. 937-944.

[56] Singh R, Axtell JD (1973) High lysine mutant gene (hl) that improves protein quality and biological value of grain sorghum. Crop Sci 13:535-539.

[57] Stemler, A.B.L., Harlan, J.R. and de Wet, J.M.J. (1977). The sorghums of Ethiopia. Economic Botany 31:446-460.

[58] Tesfaye, K. (2017) 'Genetic diversity study of sorghum ( Sorghum bicolor ( L .) Moench ) genotypes , Ethiopia', 9, pp. 44-54. doi: 10.1515/ausae-2017-0004.

[59] Teshome, A., Patterson, D., Torrance, J. K. and Arnason, J.T. (2007). Changes of Sorghum bicolor landrace diversity and farmers' selection criteria over space and time, Ethiopia. Genetic resource and crop evolution. 54:1219-1233.

[60] Tesso T, Kapran I, Grenier C, Snow A, Sweeney P, Pedersen J, Ejeta G, et al (2008) The Potential for Cropto-Wild Gene Flow in Sorghum in Ethiopia and Niger: A Geographic Survey. Crop Sci 48:1425-1431.

[61] Tesso T, Tirfessa A, Mohammed H. (2011). Association between morphological traits and yield components in the durra sorghums of Ethiopia. Hereditas 148:98-109.

[62] Tolk JA, Howell TA, Miller FR. (2013). Yield component analysis of grain sorghum grown under water stress. Field Crop Rese 145:44-51.

[63] Vavilov, N.I. (1951). The origin, variation, immunity and breeding of cultivated plants. Chron. Bot., 13: 1366.

[64] Venkateswaran K., Muraya M, Dwivedi SL, Upadhyaya (2015) Wild sorghum- their potential use in crop improvement. IN; Wang YH, Upadhyaya HD, Kole C (eds) Genetics, Genomics and Breeding of sorghum. pp 56-81.CRC Press, New York.

[65] Williams JGK, Kubelik RA, Livak KJ, Rafalski JA, Tingey SV (1990) DNA polymorphisms amplified by arbitrary primers are useful as genetic markers. Nucleic Acids Res 18:6531-6535.

[66] Wortmann CS, Mamo M, Mburu C, Letayo E, Abebeb G, Kayuki KC, Chisi M, Mativavarira M, Xerinda S, Ndacyayisenga t (2009) Atlas of sorghum production in Eastern and Souther Africa. The University of Nebraska.

[67] Yilma K., 1991.Th role of Ethiopia sorghum germplsama resources in national breeding program Pp.315322 in:J.M. Engale, J.G.Hawakes and M. Woredae, eds. Plant resources of Ethiopia. Cambridge University Press.

[68] Yitayeh, Z. S. (2019) 'The Genetic Improvement of Sorghum in Ethiopia : Review', 9(3), pp. 51-60. doi: 10.7176/JBAH.

[69] Zietkiewicz E, Rafalski A, Labuda D (1994) Genome fingerprinting by simple sequence repeat (SSR)anchored polymerase chain reaction amplification. Genomics 20: 176-183.

Citation: Werkissa Yali Kebbede., “Genetic Variability and Divergence in Sorghum: Review” International Journal of Research Studies in Agricultural Sciences (IJRSAS), 2020; 6(5), pp. 11-20, http://dx.doi.org/ 10.20431/2454-6224.0605002

Copyright: (C) 2020 Authors. This is an open-access article distributed under the terms of the Creative Commons Attribution License, which permits unrestricted use, distribution, and reproduction in any medium, provided the original author and source are credited. 